\title{
Antioxidant effects of Etlingera elatior flower extract against lead acetate - induced perturbations in free radical scavenging enzymes and lipid peroxidation in rats
}

Tan Jackie ${ }^{1}$, Nagaraja Haleagrahara ${ }^{1 *}$, Srikumar Chakravarthi ${ }^{2}$

\begin{abstract}
Background: Etlingera elatior or 'pink torch ginger' (Zingiberaceae) are widely cultivated in tropical countries and used as spices and food flavoring. The purpose of this study was to evaluate the antioxidant effects of Etlingera elatior against lead - induced changes in serum free radical scavenging enzymes and lipid hydroperoxides in rats.

Findings: Rats were exposed to lead acetate in drinking water (500 ppm) for 14 days alone or plus the ethanol extract of E. elatior (50, 100 and $200 \mathrm{mg} / \mathrm{kg}$ ). Blood lead levels, lipid hydroperoxides, protein carbonyl contents and oxidative marker enzymes were estimated. Lead acetate in drinking water elicited a significant increase in lipid hydroperoxides (LPO) and protein-carbonyl-contents (PCC). There was a significant decrease in total antioxidants, superoxide dismutase, glutathione peroxidase and glutathione S-transferase levels with lead acetate treatment. Supplementation of E. elatior was associated with reduced serum LPO and PCC and a significant increase in total antioxidants and antioxidant enzyme levels.
\end{abstract}

Conclusions: The results suggest that flower extract of Etlingera elatior has powerful antioxidant effect against lead - induced oxidative stress and the extract may be useful therapeutic agent against lead toxicity. However, detailed evaluations are required to identify the active antioxidant compounds from this plant extract.

\section{Background}

Lead $(\mathrm{Pb})$ is a toxic metal that induces a wide range of behavioral, biochemical and physiological effects in humans. Even though blood lead levels continue to decline over the past two decades, specific populations like infants, young children and working class are still at a higher risk [1,2]. As lead exposure tends to be sub acute, produces only subtle clinical symptoms. Chronic exposure cases are more common than acute toxicity. Lead via gastro intestinal absorption is first taken up by the red blood cells and is distributed to all vascular organs [3]. Pathogenesis of lead poisoning is mainly attributed to lead-induced oxidative stress. Chronic lead exposure is known to disrupt the pro oxidant/antioxidant balance existing within the mammalian cells

\footnotetext{
* Correspondence: hsnagaraja@gmail.com

'Human Biology Division, School of Medicine, International Medical

University, Kuala Lumpur, Malaysia

Full list of author information is available at the end of the article
}

[4,5]. Lead is reported to cause oxidative stress by generating the release of reactive oxygen species (ROS) such as superoxide radicals, hydrogen peroxide and hydroxyl radicals and lipid peroxides [6-8].

As oxidative stress has been mainly implicated in the lead toxicity, reducing the possibility of lead acetate interacting with cellular metabolism biomolecules and decreasing the reactive oxygen species generation by the use of antioxidant nutrients has received considerable attention in the recent past $[4,9,10]$. There has been increased interest among phytotherapy researchers to use medicinal plants with antioxidant activity for protection against heavy metal toxicity $[6,8]$.

Etlingera elatior, also known as 'torch ginger' or 'red ginger lily' belongs to zingiberaceae family and is a herbaceous perennial plant native to South East Asia. It is known as bunga kecombrang or honje in Indonesia and as bunga kantan in Malaysia. Flowers of E. elatior are in shades of pink and red and the inflorescence of the 
plant are borne on erect stalk of the plants. More than 15 species of Etlingera plants have been recorded in Peninsular Malaysia [11,12]. The young shoots and flower buds of the plants are consumed raw by indigenous communities in Malaysia and Thailand. Inflorescence of E. elatior is used for flavoring the food and also as ornamentals. The flowers and flower buds are commonly used in Malaysian dishes such as, Penang laksa, nasi kerabu and nasi ulam [11,13-15].

E. elatior has been well known for its medicinal properties among indigenous communities in Malaysia. Decoction prepared from the fruit of E. elatior has been used to treat ear ache and the leaves have been used in wound healing. The young flower shoot of E. elatior was reported to have antimicrobial, cytotoxic and anti-tumor promoting properties [16]. E.elatior inflorescence is known to have high antioxidant properties $[17,18]$. Literature is scanty regarding the phytochemical studies conducted on the inflorescence of E. elatior. Most of the previous studies on the antioxidant activities of E. elatior were limited to rhizomes and leaves. There are no reports available on the antioxidant activities of inflorescence of E. elatior against lead induced toxicity. Hence the present study was taken up to assess the effects of ethanol extract of $E$. elatior flower on serum free radical scavenging enzymes and lipid hydroperoxides in lead acetate - induced toxicity in rats.

\section{Methods}

\section{Chemicals and Plant material}

Lipid hydroperoxide (LPO), protein carbonyl content (PCC), superoxide dismutase (SOD), glutathione peroxidase (GPX), glutathione S-transferase (GST) assay kits were purchased from Cayman Chemicals (Cayman Chemicals and Pierce Biotechnology, USA). Lead acetate (99.5\%) was purchased from Sigma Chemical Co. (St. Louis, MO, USA). The inflorescence of the Etlingera elatior plant was used in this research because it is eaten by the local population. Twelve kg of Etlingera elatior inflorescence was collected from a nursery in Sungai Buloh, Kuala Lumpur, Malaysia, in August 2008 and was authenticated by Department of Horticulture, University Putra Malaysia. The voucher specimen was deposited in the research laboratory at International Medical University (voucher specimen: IMU/PMR/2008/ 01).

\section{Plant extraction}

Inflorescence of Etlingera elatior washed in running tap water three times and cut into $3 \mathrm{~cm}$ pieces and again washed and soaked in running tap water for five minutes then air dried. The fresh, dried petals $(500 \mathrm{~g})$ were extracted thrice with $95 \%$ ethanol $(1: 10 \mathrm{w} / \mathrm{v})$ using a soxhlet apparatus set at $50^{\circ} \mathrm{C}$ for $3 \mathrm{hrs}$. The extract was filtered, evaporated in vacuum evaporator and lypholized to give yield of about $60 \mathrm{~g}$ of dry extract. The final product was a pink/purplish fine powder that bears the ginger aroma. The powder was stored in $50 \mathrm{ml}$ polypropylene tubes away from direct light sources at $4^{\circ} \mathrm{C}$ till further use. The extract was reconstituted with distilled water to give desired concentrations used in this study.

\section{Phytochemical evaluation}

The Etlingera elatior inflorescence extract was tested for the presence of various phytochemical classes of compounds such as alkaloids, phenolic compounds, flavonoids, tannins, and saponins using standard procedures of analysis $[19,20]$.

Test for alkaloids

$1 \mathrm{~cm}^{3}$ of $\mathrm{HCl}$ was added to $3 \mathrm{~cm}^{3}$ of each extract in a test tube. The mixture was heated for 20 minutes, cooled and filtered. 2 drops of Wagner's reagent was added to $1 \mathrm{~cm}^{3}$ of the filtrate and observed for reddish brown precipitate.

\section{Test for tannins}

(a) $1 \mathrm{~cm}^{3}$ of freshly prepared $10 \% \mathrm{KOH}$ was added to 1 $\mathrm{cm}^{3}$ of each of the extracts and observed for dirty white precipitate.

(b) Two drops of $5 \% \mathrm{FeCl}_{3}$ was added to $1 \mathrm{~cm}^{3}$ of the extracts and observed for green precipitate.

\section{Test for flavonoids}

To $3 \mathrm{~cm}^{3}$ of each extract was added $1 \mathrm{~cm}^{3} \mathrm{NaOH}$ and observed for yellow colouration.

\section{Test for glycosides}

$10 \mathrm{~cm}^{3}$ of $50 \% \mathrm{H}_{2} \mathrm{SO}_{4}$ was added to $1 \mathrm{~cm}^{3}$ of the extract in a test tube. The mixture was heated in a boiling water-bath for 15 minutes. $10 \mathrm{~cm}^{3}$ of Fehling's solution was added and the mixture was boiled and observed for brick red precipitate.

\section{Test for saponins}

$2 \mathrm{~cm}^{3}$ of each extract in a test tube was vigorously shaken for two minutes and observed for persistent foaming.

\section{Animals and Experimental design}

Three months old male Sprague Dawley rats weighing 180 - 200 g were purchased from University Kebangsaan Malaysia (UKM), Kuala Lumpur, Malaysia, and housed under standard laboratory conditions $\left(25 \pm 2^{\circ} \mathrm{C} ; 12 \mathrm{~h}\right.$ light/dark cycles). The rats had access to an animal diet and tap water ad libitum. The rats were placed in polypropylene cages with three animals per cage and were allowed to acclimatize for one week prior to treatment.

All the experimental protocols conducted on rats were performed in accordance with the internationally accepted principles for laboratory animal use and care and Institutional animal care and use committee and the study got approval from the Research and Ethics committee. 
Animals were divided randomly into the following groups with eight animals in each group. Group 1: control; Group 2: rats exposed to lead acetate in drinking water (500 ppm); Groups 3-5: received E. elatior (50, 100 and $200 \mathrm{mg} / \mathrm{kg}$ b.w). Group 4: Rats exposed to lead acetate and treated with E. elatior. Groups 6 - 8: received lead acetate in drinking water and E. elatior at the same dose daily for 14 days. E. elatior extract was diluted with distilled water to the desired concentration of 50,100 and $200 \mathrm{mg} / \mathrm{kg}$ body weight and was orally administrated to rats $(0.5 \mathrm{ml} / \mathrm{rat} /$ day $)$.

At the end of experimental period, rats were anaesthetized with diethyl ether and blood was collected by cardiac puncture. Serum was separated and used for the determination of lipid hydroperoxides (LPO), total antioxidants, protein carbonyl content (PCC), superoxide dismutase (SOD), glutathione peroxidase (GPx) and glutathione S-transferase (GST). All biochemical parameters were assayed according to the standard procedures using ELISA kits (Cayman Chemicals and Pierce Biotechnology USA). Whereas, protein levels were estimated by protein assay kits from Cayman Chemicals (Cayman Chemicals and Pierce Biotechnology, USA). Furthermore, blood lead levels were assayed by graphite furnace atomic absorption spectrophotometry method.

\section{Total antioxidant assay}

Using the total antioxidant assay kit, aqueous and lipid soluble antioxidants were not separated and thus combined antioxidant activities of all its constituents were assessed. The assay relies on the ability of antioxidants in the sample to inhibit the oxidation of ABTS (2, 2'Azino-di-[3-ethylbenzthiazoline sulphonate]) to $\mathrm{ABTS}^{\circledR \cdot+}$ by metmyoglobin. The amount of ABTS produced was monitored by reading the absorbance at $405 \mathrm{~nm}$.

\section{Lipid Hydroperoxide (LPO) assay}

A quantitative extraction method as provided in the kit method for lipid hydroperoxide assay was used to extract lipid hydroperoxides into chloroform and the extract was directly used. This procedure eliminates any interference caused by hydrogen peroxide or endogenous ferric ions in the sample and provides a sensitive and reliable assay for lipid peroxidation. The absorbance was read at $500 \mathrm{~nm}$ using a 96 well plate spectrophotometric reader and a dose response curve of the absorbance unit vs. concentration in nmol was generated.

\section{Protein carbonyl content (PCC) assay}

In the protein carbonyl content assay kit, protein samples are derivatized by making use of the reaction between 2, 4-dinitrophenylhydrazine (DNPH) and protein carbonyls. Formation of a Schiff base produces the corresponding hydrazone which was analyzed spectrophotometrically at $360-385 \mathrm{~nm}$.

\section{Superoxide dismutase (SOD) assay}

This assay kit utilizes a tetrazolium salt for the detection of superoxide radicals $\left(\mathrm{O}_{2}{ }^{-}\right)$generated by xanthine oxidase and hypoxanthine. One unit of SOD is defined as the amount of enzyme necessary to exhibit $50 \%$ dismutation of the superoxide radical. Oxidation rate of tetrazolium salt to formazan dye by $\mathrm{O}_{2}{ }^{-}$is inversely proportional to the endogenous activity of SOD. The formazan dye stains the wells and its staining intensity was detected by absorbance spectrophotometry at 450 nm using a plate reader.

\section{Glutathione peroxidase (GPx) assay}

This assay kit measured GPx activity indirectly by a coupled reaction with glutathione reductase. Oxidized glutathione, produced upon reduction of an organic hydroperoxide by $\mathrm{GPx}$, is recycled to its reduced state by glutathione reductase and NADPH. The oxidation of NADPH to $\mathrm{NADP}^{+}$is accompanied by a decrease in absorbance at $340 \mathrm{~nm}$. The rate of decrease in the absorbance at 340 was directly proportional to the GPx activity in the sample.

\section{Glutathione S-transferase (GST) assay}

The Cayman Chemical GST assay kit measured total GST activity (cytosolic and microsomal) by measuring the conjugation of 1-chloro-2, 4-dinitrobenzene (CDNB) with reduced glutathione. The conjugation is accompanied by an increase in absorbance at $340 \mathrm{~nm}$. The rate of increase is directly proportional to the GST activity in the sample.

\section{Data analysis and statistics}

Data were expressed as mean \pm standard deviation. Statistical analysis was done by Graph Pad Prism 5.0 software package. Statistical differences among various groups and the significance were calculated by non-parametric Kruskal Wallis and Mann- Whitney's U-Tests. P value less than 0.05 was considered statistically significant.

\section{Results}

\section{Phytochemical screening}

Phytochemical screening study of Etlingera elatior inflorescence extract revealed that the extract had significant quantity of phenolic compounds and flavonoids but no tannins, alkaloids and saponins were detected (table 1). The total phenolic content of the ethanolic extract was $424 \pm 62 \mathrm{mg}$ gallic acid equivalent (GAE) per gram of extract. The total flavonoid content of the extract was $772 \pm 34 \mathrm{mg}$ GAE per g of extract.

\section{Blood lead levels}

There was a significant increase in lead level in the serum of rats in the lead acetate alone-treated group. Whereas, no significant differences were found between 
Table 1 The analysis of phytochemicals in the ethanolic extract of inflorescence of $E$. elatior

\begin{tabular}{ll}
\hline Phytochemicals & Ethanol Extract of E. elatior \\
\hline Alkaloids & - \\
\hline Glycosides & + \\
\hline Tannins & - \\
\hline Saponin & - \\
\hline Flavonoids & ++ \\
\hline Phenols & ++ \\
\hline & + Presence of compound in moderate amount; ++ Presence of compound in \\
significant amount; - absent.
\end{tabular}

the groups, that received the combined treatment or lead acetate and the extract at 50 and $100 \mathrm{mg}$. Moreover, animals treated with lead acetate plus the extract at the highest dose $(200 \mathrm{mg})$ showed a significant decrease in serum lead level compared to the other treated groups (Figure 1).

\section{Total antioxidants}

Animals treated with lead acetate alone showed a significant decrease in serum total antioxidants $(\mathrm{p}<0.05)$ whereas, those treated with the extract alone at the three tested doses showed a significant increase in total antioxidants. Animals received the combined treatment of lead acetate and the extract at the three tested doses showed a significant improvement in total antioxidants $(\mathrm{p}<0.05)$. This improvement was more pronounced in the group received lead acetate and treated with the highest dose of E. elatior $(200 \mathrm{mg} / \mathrm{kg}$ b.w) $(\mathrm{p}<0.05)$ (Figure 2$)$.

\section{Lipid hydroperoxides}

The current results revealed that animals treated with lead acetate alone showed a significant increase in LPO compared to the other experimental groups $(\mathrm{p}<0.05)$. Animals treated with E. elatior at the tested doses were comparable to the control regarding LPO level. The

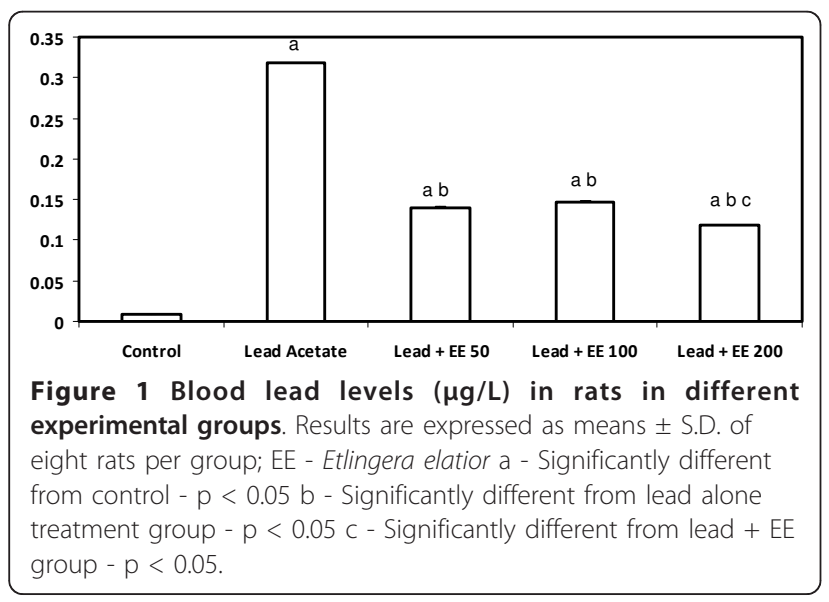

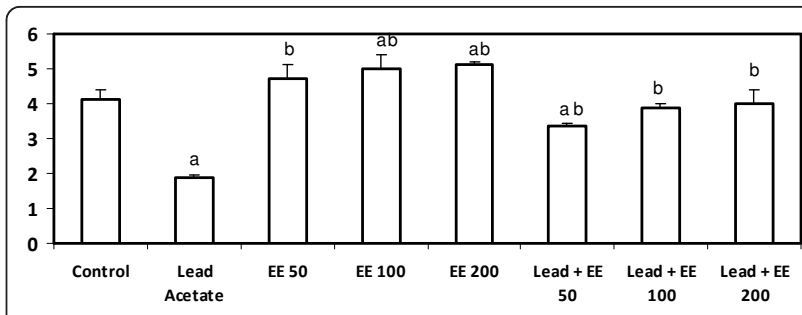

Figure 2 Serum total antioxidants level ( $\mu \mathrm{mol} / \mathrm{mg}$ protein) in control and E. elatior alone or in combination with lead acetate-treated rats. Results are expressed as means \pm S.D. of eight rats per group; EE - Etlingera elatior a - Significantly different from control $-p<0.05 b$ - Significantly different from lead alone treatment group $-p<0.05$.

combined treatment of lead acetate plus the extract resulted in a significant decrease $(\mathrm{p}<0.05)$ in LPO resulted from Lead exposure although these levels were still higher than the control group (Figure 3).

\section{Protein carbonyl content}

A significant increase in serum protein carbonyl contents were recorded in lead-treated animals $(\mathrm{p}<0.05)$. More than $30 \%$ increase in protein carbonyl content was seen in this group. The level of PCC decreased significantly when $E$. elatior was administrated to the lead acetate-treated groups $(\mathrm{p}<0.05)$. Moreover, the decrease in PCC was pronounced in the group treated with E. elatior at the highest dose $(200 \mathrm{mg} / \mathrm{kg} \mathrm{b.w})$. Though the level of PCC was significantly reduced with concurrent E. elatior treated rats, it did not significantly decrease below the control levels (Figure 4). It is of interest to mention that all groups treated with $E$. elatior alone or in combination with lead acetate did not show any significant differences among them or between the control groups.

\section{Superoxide dismutase}

Serum superoxide dismutase showed a significant decrease $(\mathrm{p}<0.05)$ in lead-treated group and a significant increase in E. elatior - treated groups compared to the control group $(\mathrm{p}<0.05)$. Furthermore, the increase in SOD in E. elatior - treated groups was dose-dependent and it was higher than the control when the extract was administrated at the highest dose. On the other hand, the combined treatment with the extract and lead resulted in a significant improvement ( $\mathrm{p}<$ 0.05) in SOD towards the control level although these treatments did not normalize SOD level except the group received the extract at the highest dose which was comparable to the control group (Figure 5).

\section{Glutathione peroxidase}

The current study revealed that GPx was significantly decreased in animals treated with lead acetate alone $(p$ 


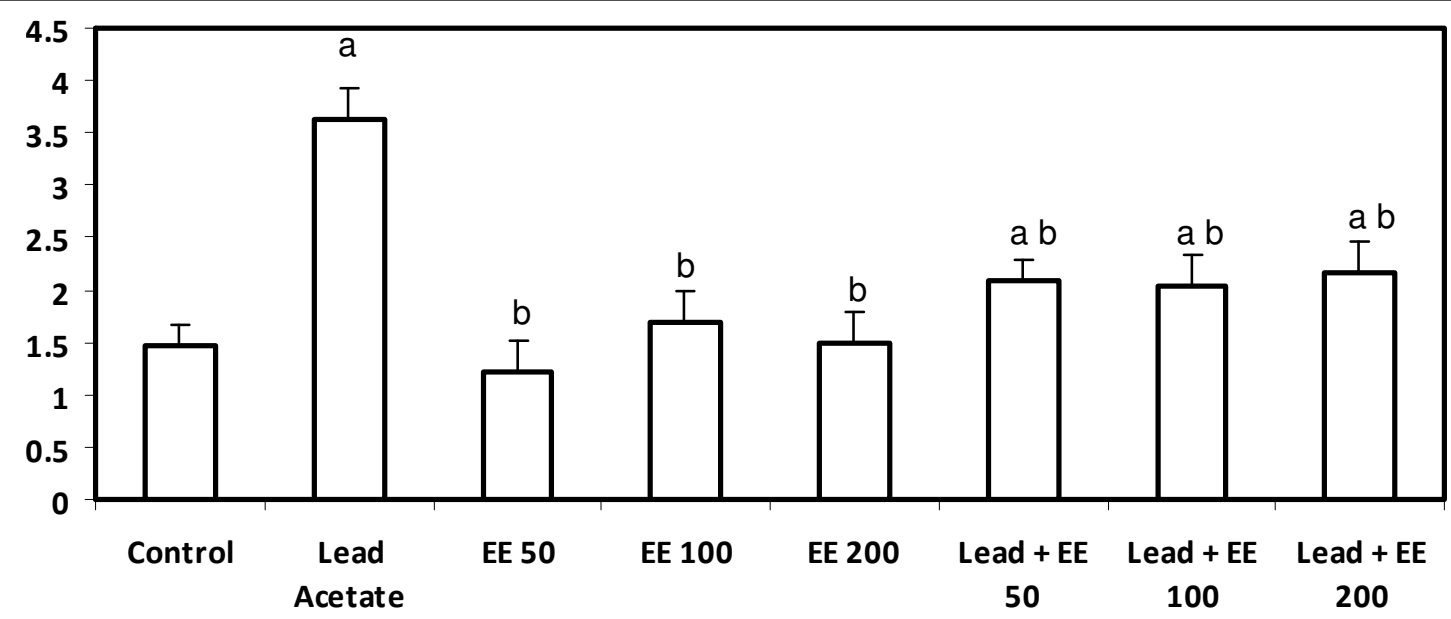

Figure 3 Lipid hydroperoxide levels ( $\mathrm{nmol} / \mathrm{mg}$ protein) in control and E. elatior alone or in combination with lead acetate-treated rats. Results are expressed as means \pm S.D. of eight rats per group; EE - Etlingera elatior a - Significantly different from control - $p<0.05 b-$ Significantly different from lead alone treatment group $-p<0.05$.

$<0.05)$. Animals received the extract at the three tested doses showed a significant increase compared to the control group. Whereas, the combined treatment with lead and the extract at the three levels succeeded to induce a significant improvement $(\mathrm{p}<0.05)$ in GPx, compared to lead alone-treated group, these treatments failed to normalize GPx (Figure 6).

\section{Glutathione S-transferase}

Animals treated with lead alone showed a significant decrease $(\mathrm{p}<0.05)$ in GST level compared to the control group. The extract alone at lowest dose $(50 \mathrm{mg} / \mathrm{kg}$ b.w) did not affect GST significantly whereas the other tested doses induced a significant increase compared to the control group. The combined treatment with lead and the extract resulted in a significant improvement $(\mathrm{p}<0.05)$ in GST compared to lead acetate alonetreated group but failed to normalize it. The best result

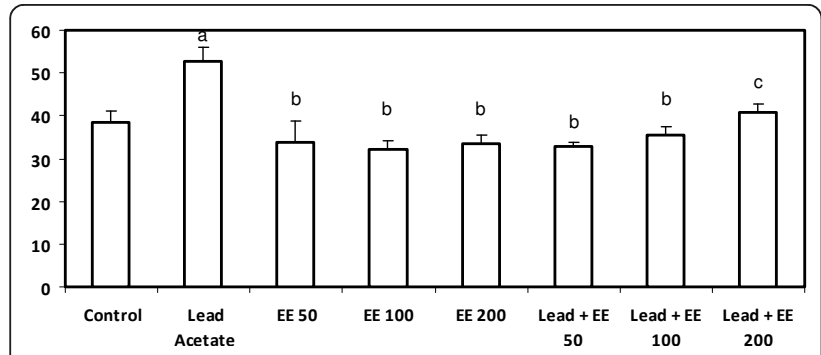

Figure 4 Serum protein carbonyl content ( $\mathrm{nmol} / \mathrm{mg}$ protein) in control and E. elatior alone or in combination with lead acetate-treated rats. Results are expressed as means \pm S.D. of eight rats per group; EE - Etlingera elatior a - Significantly different from control $-p<0.05 b$ - Significantly different from lead alone treatment group - $p<0.05 c-$ Significantly different from lead + EE group $-\mathrm{p}<0.05$. achieved in the group treated with lead and the extract at $100 \mathrm{mg} / \mathrm{kg}$ b.w. (Figure 7 ).

\section{Discussion and conclusion}

Lead is known to cause oxidative damage in various tissues by bringing about imbalance in the generation and removal of reactive oxygen species [21-23]. Although the exact mechanisms by which lead induces oxidative stress in various tissues are not completely understood, evidence indicates that multiple mechanisms may be involved. Numerous plant products have been shown to have high potent antioxidant activity. Recently, bioflavonoids and polyphenols of plant origin have been used extensively for free radical scavenging and to inhibit lipid peroxidation $[8,24]$.

The present study showed that lead acetate exposure in drinking water for 14 days resulted in severe oxidative stress. The selective dose of lead acetate used in the

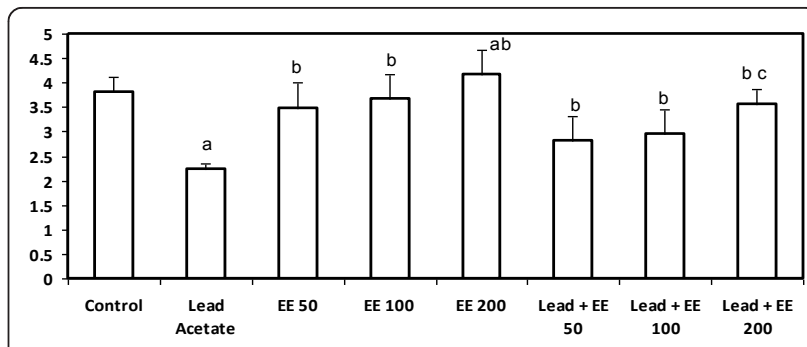

Figure 5 Serum superoxide dismutase level (U/mg protein) in control and E. elatior alone or in combination with lead acetate-treated rats. Results are expressed as means \pm S.D. of eight rats per group; EE - Etlingera elatior a - Significantly different from control - $p<0.05 b$ - Significantly different from lead alone treatment group - $p<0.05 c-$ Significantly different from lead + EE group $-p<0.05$. 


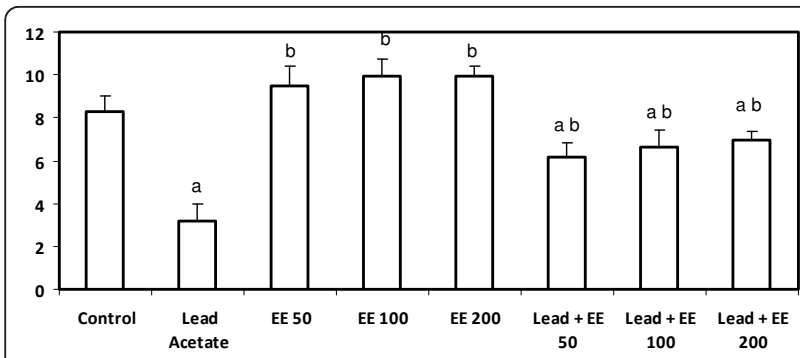

Figure 6 Serum glutathione peroxidase level ( $\mathrm{nmol} / \mathrm{mg}$ protein) in control and $E$. elatior alone or in combination with lead acetate-treated rats. Results are expressed as means \pm S.D. of eight rats per group; EE - Etlingera elatior a - Significantly different from control $-p<0.05 b$ - Significantly different from lead alone treatment group $-p<0.05$.

current study was based on previous literature [24,25]. There was increase in serum lipid hydroperoxide and protein carbonyl content and decrease in total antioxidants and antioxidant enzymes like superoxide dismutase, glutathione peroxidase and glutathione S-transferase levels. These observations confirm the findings of several studies, which reported alterations in antioxidant enzyme activities in lead exposed animals [6,9,26-28] and workers $[29,30]$ and suggest a possible involvement of oxidative stress in the pathophysiology of lead toxicity. But it is not clear whether the changes in serum antioxidant enzymes are the cause of oxidative damage or a consequence of it.

There was a significant increase in serum lipid hydroperoxides and protein carbonyl contents after lead acetate exposure. Lead is known to produce oxidative damage in various organs by increasing lipid peroxidation [31,32]. Lipid peroxidation will inactivate cell constituents by oxidation and ultimately lead to loss of membrane integrity [6,33]. The observed increased lipid hydroperoxides in the current study in lead-treated group may be due to the formation of free radicals or through exhaustion of antioxidants, leading to oxidative

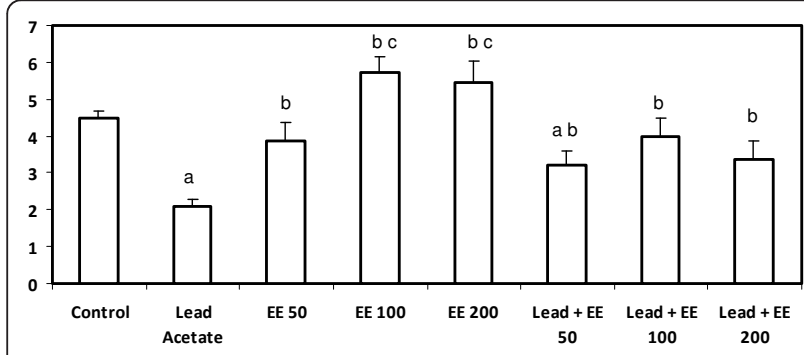

Figure 7 Serum glutathione S-transferase level ( $\mu \mathrm{mol} / \mathrm{h} / \mathrm{mg}$ protein) in control and $E$. elatior alone or in combination with lead acetate-treated rats. Results are expressed as means \pm S.D. of eight rats per group; EE - Etlingera elatior a - Significantly different from control $-p<0.05 b$ - Significantly different from lead alone treatment group - $p<0.05 c$ - Significantly different between EE alone groups $-p<0.05$. stress. Intense lipid peroxidation caused by lead exposure may affect the mitochondrial and cytoplasmic membrane causing more severe oxidative damage in the tissues and consequently releasing lipid hydroperoxides into circulation [34,35]. Protein modifications elicited by direct oxidative attack lead to the formation of protein carbonyl derivatives and protein carbonyl content (PCC) is the most commonly used biomarker for protein oxidation [36-38]. The observed increase in protein carbonyl content in lead exposed rats confirms the oxidative stress induced by lead acetate in different tissues.

Treatment with lead acetate significantly decreased the activities of superoxide dismutase, glutathione peroxidase, glutathione S- transferase and total antioxidants level. These results are in agreement with previous reports $[24,25,39]$. Lead acetate is known to cause free radical damage in tissues by two mechanisms: Increased generation of ROS, including hydroperoxides, singlet oxygen and hydrogen peroxides, and by causing direct depletion of antioxidant reserves [22,40]. Superoxide dismutase, glutathione peroxidase and glutathione S-transferase enzymes take part in maintaining glutathione homeostasis in the tissues. These antioxidant enzymes are involved in the defense system against free radical mediated tissue or cellular damage after lead exposure $[24,41,42]$. The observed decrease in circulating antioxidants and decrease in serum total antioxidants confirm the lead acetate - induced depletion of antioxidants depletion.

In the present study, administration of ethanol extract of Etlingera elatior alone significantly increased the serum antioxidant enzymes. Treatment of E. elatior extract along with lead acetate treatment decreased the lead induced changes in lipid hydroperoxides and antioxidant enzyme levels. Results on blood lead levels (BLL) showed that lead acetate alone showed a significantly higher BLL compared to concurrent E. elatior and lead groups. Following oral intake, absorbed lead acetate is carried via blood to various tissues and more than $90 \%$ of blood lead is transported in the erythrocytes as lead phosphate $[43,44]$. This might have elevated blood lead levels in lead acetate ingested rats. The observed decrease in blood lead levels in E. elatior with lead acetate treatment group implies the possible chelating effect of E. elatior extract. However, this property of Etlingera elatior extract requires further study.

Relatively few data are available regarding the antioxidant effect of E. elatior plant extract. Although the flower and flower shoots of this plant have been used for food, there are no studies on the possible antioxidant effect of E. elatior flower extract till recently. Previous studies conducted in our laboratory showed that the inflorescence extract of the plant has powerful antioxidant activities against lead induced oxidative stress in liver and bone marrow $[17,18]$. E. elatior has decreased 
the lipid hydroperoxides and protein carbonyl contents after lead acetate exposure in the bone marrow and liver of rats. The study also showed that there was a significant increased production of antioxidant enzymes like super oxide dismutase, glutathione peroxidase and glutathione S - transferase with E. elatior treatment $[17,18]$. Most of the past studies on the antioxidant activities of E. elatior were confined to rhizomes $[16,45]$ and leaves [11]. The rhizomes extract have been reported to have high antioxidant properties comparable to $\alpha$ - tocopherol. Habsah et al [16] reported that crude dichloromethane and methanol extracts of $E$. elatior leaves possessed antioxidant and antitumor promoting activity. In a comparative study Chan et al., [11] compared five species of Etlingera for their anti-oxidative properties. Among them E. elatior ranked highest in total phenolic content (TPC) and ascorbic acid equivalent antioxidant capability (AEAC) [46]. In a study on the antioxidant activities of inflorescences and rhizomes from E. elatior, inflorescence showed higher total phenolic content and antioxidant activities than rhizomes [11]. The salient finding from the current study regarding antioxidant effects is that $E$. elatior nearly normalized the perturbations of serum antioxidant enzymes, lipid hydroperoxides and protein carbonyl contents. The present study also showed a significant dose dependent effect of $E$. elatior against lead acetate - induced oxidative stress; the higher concentration of the extract $(200 \mathrm{mg} / \mathrm{kg})$ had produced a marked improvement in the total antioxidants and superoxide dismutase and produced a significant reduction in protein carbonyl contents in the lead treated group after 14 days confirming earlier reports [18].

The observed antioxidant activities of E. elatior flower extract against lead induced toxicity could be attributed to the antioxidant compounds present in the extract [17]. Phytochemical screening revealed significant amounts of polyphenolic and flavonoid compounds in the extract. These antioxidant compounds could have played a major role in scavenging the reactive oxygen species induced by lead acetate in the serum.

This study has shown that E. elatior ethanol extract from the inflorescence had significant antioxidant activity and caused a significant reversal of the lead induced changes in the oxidative biomarkers in serum. Observed changes could be due to the different polyphenols, flavonoids, and flavones present in the extract. The results prove for the first time that E. elatior inflorescence extract has free radical scavenging and antioxidant properties.

\section{Acknowledgements}

The authors wish to thank Dr Mallikarjuna Rao for his help in getting the voucher specimen and International Medical University for the research grant.

\section{Author details}

'Human Biology Division, School of Medicine, International Medical University, Kuala Lumpur, Malaysia. ${ }^{2}$ Pathology Division, School of Medicine, International Medical University, Kuala Lumpur, Malaysia.

\section{Authors' contributions}

TJ carried out the laboratory studies, collection of plant materials, helped in analysis of data and preparation of manuscript, $\mathrm{NH}$ helped in animal experiments, laboratory studies and preparation of manuscript and analysis and interpretation of the data, SC involved in laboratory work, revising the manuscript and interpretation of data. All authors read and approved the manuscript.

\section{Competing interests}

The authors declare that they have no competing interests.

Received: 24 January 2011 Accepted: 17 March 2011

Published: 17 March 2011

\section{References}

1. Godwin HA: The biological chemistry of lead. Curr Opin Chem Biol 2001, 5:223-27.

2. Goyer RA: Lead toxicity: from overt to subclinical to subtle health effects. Environ Health Perspect 1990, 86:177-81.

3. Georing PL: Lead-protein interaction as a basis for lead toxicity. Neurotoxicol 1993, 14:45-60.

4. Hsu CP, Guo LY: Antioxidant nutrients and lead toxicity. Toxicol 2002, 180:33-44.

5. Senapati SK, Dey S, Dwivedi SK, Swarup D: Effect of garlic (Allium sativum L.) extract on tissue lead levels in rats. J Ethnopharmacol 2001, 76:229-32.

6. El-Nekeety AA, El-Kady AA, Soliman MS, Hassan NS, Abdel-Wahhab MA: Protective effect of Aquilegia vulgaris (L.) against lead acetate-induced oxidative stress in rats. Food Chem Toxicol 2009, 47:2209-15.

7. Hsu PC, Liu MY, Hsu CC, Chen LY, Leon GY: Lead exposure causes generation of reactive oxygen species and functional impairment in rat sperm. Toxicol 1997, 122:133-43.

8. Xu Y, Li G, Han C, Sun L, Zhao R, Cui S: Protective effect of Hippophae rhamnoides L. juice on lead-induced neurotoxicity in mice. Biol Pharm Bull 2005, 28:490-94.

9. Gurer H, Ercal N: Can antioxidants be beneficial in the treatment of lead poisoning? Free Radical Biol and Med 2000, 29:927-45.

10. Patra RC, Swarup D, Dwivedi SK: Antioxidant effects of a-tocopherol, ascorbic acid and L-methionine on lead induced oxidative stress to the liver, kidney and brain in rats. Toxicol 2001, 162:81-88.

11. Chan EW, Lim CYY, Omar Mohammed: Antioxidant and antibacterial activity of leaves of Etlingera species (Zingiberaceae) in Peninsular Malaysia. Food Chem 2007, 104:1586-93.

12. Lim CK: Taxonomic notes on Etlingera Giseke (Zingiberaceae) in Peninsular Malaysia: the "chasma" taxa and supplementary notes on the "Nicolaia" taxa. Folia Malaysiana 2001, 2:141-78.

13. Khaw SH: The genus Etlingera (Zingiberaceae) in Peninsular Malaysia including a new species. Gardens' Bull Singapore 2001, 53:191-39.

14. Larsen K, Ibrahim H, Khaw SH, Saw LG: Gingers of Peninsular Malaysia and Singapore Kota Kinabalu: Natural History Publications (Borneo); 1999, 135.

15. Noweg T, Abdullah AR, Nidang D: Forest plants as vegetables for communities bordering the Crocker Range National Park. ASEAN Review of Biodiversity and Environmental Conservation (ARBEC) (January-March) 2003, $1-18$.

16. Habsah M, Ali M, Lajis NH, Sukari MA, Yap YH, Kikuzaki H, Nakatani N: Antitumor promoting and cytotoxic constituents of Etlingera Elatior. Malaysian J Med Sci 2005, 12:6-12.

17. Haleagrahara N, Jackie T, Chakravarthi S, Rao M, Anupama K: Protective effect of Etlingera elatior (torch ginger) extract on lead acetate - induced hepatotoxicity in rats. J Toxicol Sci 2010, 35:663-71.

18. Haleagrahara N, Jackie T, Chakravarthi S, Rao M, Pasupathi T: Protective effects of Etlingera elatior extract on lead acetate-induced changes in oxidative biomarkers in bone marrow of rats. Food Chem Toxicol 2010, 48:2688-2694.

19. Khan A, Gilani AH: Pharmacodynamic evaluation of Terminalia Bellerica for its antihypertensive effects. J Food Drug Anal 2008, 16:6-14. 
20. Silva GL, Lee I, Kinghorn AD: Special problems with the extraction of plants. In Methods in Biotechnology (Natural product Isolation). Edited by: Cannell RJP. New Jersey: Humana press; 1998:343-363.

21. Hamadouche NA, Slimani M, Merad-Boudia B, Zaoui C: Reproductive toxicity of lead acetate in adult male rats. Am J Sci Res 2009, 3:38-50.

22. Upasani CD, Khera A, Balaraman R: Effect of lead with Vitamins E, C, or Spirulina on malondialdehyde: conjugated dienes and hydroperoxides in rats. Ind J Exp Biol 2001, 39:70-74.

23. Gurer H, Ozgunes $H$, Neal R, Spitz DR, Ercal N: Antioxidant effects of Nacetyl cysteine and succimer in red blood cells from lead-exposed rats. Toxicol 1998, 128:181-89.

24. Newairy AA, Abdou HM: Protective role of flax lignans against lead acetate - induced oxidative damage and hyperlipidemia in rats. Food Chem Toxicol 2009, 47:813-18.

25. Bokara KK, Blaylock I, Denise SB, Bettaiya R, Rajanna S, Yallapragada PR: Influence of lead acetate on glutathione and its related enzymes in different regions of rat brain. J Appl Toxicol 2009, 29:452-58.

26. McGowan C, Donaldson WE: Changes in organ non-protein sulfydryl and glutathione concentrations during acute and chronic administration of inorganic lead to chicks. Biol Trace Elem Res 1986, 10:37-46.

27. Hsu JM: Lead toxicity related to glutathione metabolism. J Nutr 1981, 111:26-33.

28. Bolin CM, Basha R, Cox D, Zawia NH, Maloney B, Lahiri DK, CardozoPelaez F: Exposure to lead and the developmental origin of oxidative DNA damage in the aging brain. FASEB J 2006, 20:788-90.

29. Sugawara E, Nakamura K, Miyake T, Fukumura A, Seki Y: Lipid peroxidation and concentration of glutathione in erythrocytes from workers exposed to lead. Br J Ind Med 1991, 48:239-42.

30. Solliway BM, Schaffer A, Pratt H, Yannai S: Effect of exposure to lead on selected biochemical and hematological variables. Pharmacol Toxicol 1996, 78:18-22.

31. Gurer H, Neal R, Yang P, Oztezcan S, Ercal N: Captopril as an antioxidant in lead-exposed Fischer 344 rats. Hum Exp Toxicol 1999, 18:27-32.

32. El-Missiry MA: Prophylactic effect of melatonin on lead induced inhibition of heme biosynthesis and deterioration of antioxidant system in male rats. J Biochem Mol Toxicol 2000, 14:57-62.

33. Abdel-Wahhab MA, Saeed A, Hufner A: NMR and radical scavenging activities of patuletin from Urtica urens $L$. against aflatoxin $B_{1}$. Pharm Biol 2005, 43:515-25.

34. Abdel-Wahhab MA, Abdel-Azim SH, El-Nekeety AA: Inula crithmoides extract protect against ochratoxin A-induced oxidative stress, clastogenic and mutagenic alterations in male rats. Toxicon 2008, 52:566-73.

35. Shabani A, Rabbani A: Lead nitrate induced apoptosis in alveolar macrophages from rat lung. Toxicol 2000, 149:109-14.

36. Shacter E: Quantification and significance of protein oxidation in biological samples. Drug Met Rev 2000, 32:307-326.

37. Beal MF: Oxidatively modified proteins in aging and disease. Free Radic Biol Med 2002, 32:797-803.

38. Sailaja $\mathrm{ROH}$, Setty $\mathrm{OH}$ : Protective effect of Phyllanthus fraternus against allyl alcohol-induced oxidative stress in liver mitochondria. $J$ Ethnopharmacol 2006, 105:201-09.

39. Dringer A: Metabolism and function of glutathione in brain. Prog Neurobiol 2000, 62:649-71.

40. Ercal N, Gurer-Orhan H, Aykin-Burns N: Toxic metals and oxidative stress part I: mechanisms involved in metal-induced oxidative damage. Curr Top Med Chem 2001, 1:529-39.

41. Neal R, Cooper K, Kellogg G, Gurer H, Ercal N: Effects of some sulfurcontaining antioxidants on lead-exposed lenses. Free Radic Biol Med 1999, 26:239-43.

42. Arai M, Imai H, Koumura T, Yoshida M, Emoto K, Umeda M, Chiba N, Nakagawa Y: Mitochondrial phospholipid hydroperoxide glutathione peroxidase plays a major role in preventing oxidative injury to cells. J Biol Chem 1999, 274:4924-33.

43. Freeman R: Chronic lead poisoning in children: a review of 90 children diagnosed in Sydney, Clinical features and investigations. Med J Aust 1970, 1:648-81.

44. Georing PL: Lead-protein interaction as a basis for lead toxicity. Neurotoxicol 1993, 14:45-60.
45. Zaeoung S, Plubrukarn A, Keawpradub N: Cytotoxic and free radical scavenging activities of Zingiberaceous rhizomes. Songklanakarin J Sci Technol 2005, 27:799-812.

46. Ibrahim H, Setyowati FM: Plant resources of South-East Asia. In Etlingera. Volume 13. Edited by: de Guzman, C.C., Siemonsma J.S. Pudoc, Wageningen; 1999:123-26.

doi:10.1186/1756-0500-4-67

Cite this article as: Jackie et al:: Antioxidant effects of Etlingera elatior flower extract against lead acetate - induced perturbations in free radical scavenging enzymes and lipid peroxidation in rats. BMC Research Notes 2011 4:67.

\section{Submit your next manuscript to BioMed Central and take full advantage of:}

- Convenient online submission

- Thorough peer review

- No space constraints or color figure charges

- Immediate publication on acceptance

- Inclusion in PubMed, CAS, Scopus and Google Scholar

- Research which is freely available for redistribution

Submit your manuscript at www.biomedcentral.com/submit
C Biomed Central 